\title{
SENYAW A FENOLIK, ORYZANOL, DAN AKTIVITAS ANTIOKSIDAN BEKATUL YANG DIFERMENTASI DENGAN Rhizopus oryzae
}

\author{
[Phenolic Compounds, Oryzanol, and Antioxidant Activity of \\ Fermented Rice Bran Using Rhizopus oryzae]
}

\author{
Faizah $^{1)}$, Feri Kusnandar ${ }^{2) \star}$, dan Siti Nurjanah ${ }^{2)}$ \\ 1) Program Studi Ilmu Pangan, Sekolah Pascasarjana, Institut Pertanian Bogor, Bogor \\ ${ }^{2)}$ Departemen Ilmu dan Teknologi Pangan, Fakultas Teknologi Pertanian, Institut Pertanian Bogor, Bogor
}

Diterima 10 Juli 2019 / Disetujui 4 Februari 2020

\begin{abstract}
Rice bran is a by-product of milled rice. It contains bioactive compounds, such as total phenolic compounds and $\gamma$-oryzanol known to have antioxidant activities. However, these bioactive compounds are chemically bound in the lignin matrix of the rice bran. Fermentation process potentially releases the bound forms of the active compounds to become the free ones. In this research, the rice brans of three varieties, i.e. Inpari 24 (red rice), inpari 30 (white rice), and koshihikari (white rice), were fermented using Rhizopus oryzae for 0, 24, 48, 72, 96 and 120 hours. Those showed highest antioxidant activities by DPPH assays were selected for further chemical composition analyses (moisture, ash, fat, protein, and carbohydrate), total phenolic compound, and $\gamma$-oryzanol. The fermentation process significantly increased $(P<0.05)$ the antioxidant activities of all rice brans and those fermented for 72 hours showed the highest antioxidant activities. This fermentation condition resulted in significant increase in moisture, ash and protein contents, while decreasing the fat and carbohydrate contents. The total phenolic compound and $\gamma$-oryzanol of the three fermented rice brans increased significantly $(P<0.05)$. The fermented rice bran of Inpari 24 variety showed the highest antioxidant activity, total phenolic compound, and $\gamma$-oryzanol contents as compared to those of Inpari 30 and Koshihikari varieties.
\end{abstract}

Keywords: antioxidant activity, fungi fermentation, rice bran, total phenolic compound, $\gamma$-oryzanol

\begin{abstract}
ABSTRAK
Bekatul merupakan hasil samping dari hasil penyosohan beras pecah kulit. Bekatul mengandung senyawa bioaktif, seperti total senyawa fenolik dan $\gamma$-oryzanol yang memiliki aktivitas antioksidan. Namun, Senyawa bioaktifini terikat secara kimia dalam matriks senyawa lignin. Proses fermentasi kapang dapat memecah komponen lignin sehingga komponen bioaktif berada dalam bentuk bebas. Penelitian ini mengkaji pengaruh fermentasi bekatul dengan menggunakan Rhizopus oryzae. Bekatul dari tiga varietas padi (Inpari 24 (beras merah), Inpari 30 (beras putih), dan Koshihikari (beras putih) difermentasi selama 0, 24, 48, 72, 96 dan 120 jam. Sampel dianalisis aktivitas antioksidannya (pengujian DPPH) dan yang menunjukkan aktivitas antioksidan tertinggi dianalisis lebih lanjut komposisi kimianya (kadar air, abu, lemak, protein, dan karbohidrat), kadar total senyawa fenolik dan $\gamma$-oryzanol. Proses fermentasi pada ketiga varietas meningkatkan aktivitas antioksidan, dan yang paling tinggi ditunjukkan pada sampel yang difermentasi selama 72 jam. Kondisi fermentasi ini meningkatkan secara nyata $(P<0,05)$ kadar air, abu dan protein, dan menurunkan kadar lemak dan protein. Kadar total fenol dan $\gamma$-oryzanol dari ketiga bekatul terfementasi juga meningkat $(P<0,05)$. Bekatul terfermentasi dari Inpari 24 menunjukkan aktivitas antioksidan, total fenol $\gamma$-oryzanol yang tertinggi dibandingkan bekatul terfermentasi dari Inpari 30 and Koshihikari.
\end{abstract}

Kata kunci: aktivitas antioksidan, bekatul, fermentasi kapang, total senyawa fenolik, $\gamma$-oryzanol

*Penulis Korespondensi: E-mail: fkusnandar@apps.ipb.ac.id 


\section{PENDAHULUAN}

Bekatul merupakan serbuk halus yang berasal dari lapisan terluar beras pecah kulit yang berwarna cokelat yang dihasilkan dari proses penggilingan padi (Sukma et al., 2010). Menurut Gul et al. (2015) penggilingan padi dan penyosohan beras dapat menghasilkan $70 \%$ beras, $20 \%$ sekam, $8 \%$ bekatul dan $2 \%$ lembaga. Produksi padi Indonesia sebesar 56,54 juta ton pada tahun 2018 (BPS, 2018) yang diperkirakan menghasilkan limbah bekatul sebesar 4,52 juta ton.

Bekatul terdiri dari lapisan perikarp, testa dan lapisan aleuron yang mengandung komponen makro, mikro dan senyawa bioaktif (Norhaizan et al., 2013). Hartati et al. (2015) melaporkan kisaran komposisi kimia bekatul dari beberapa varietas padi, yaitu air $(8,54-9,70 \%)$, abu $(9,47-10,86 \%$ bk), lemak (16,80-23,75\% bk), protein kasar $(13,20-13,37 \%$ bk), karbohidrat $(42,32-51,99 \%$ bk, by difference) dan serat kasar $(13,56-17,97 \%$ bk). Henderson et al. (2012) melaporkan senyawa bioaktif yang terdapat dalam bekatul, yaitu oryzanol, asam ferulat, asam kafeat, tricine, asam kumarat, asam fitat, vitamin $\mathrm{E}$, fitosterol, dan karotenoid. Senyawa bioaktif tersebut diketahui bermanfaat bagi kesehatan sebagai antikanker (Forster et al., 2013), antiinflamasi, antidiabetes, hipoalergenik, dan hipolipidemik (Islam et al., 2011). Jumlah bekatul dihasilkan besar, yang didukung dengan komposisi kimia dan kandungan komponen bioaktifnya yang baik, sehingga bekatul berpotensi untuk digunakan sebagai alternatif bahan pangan.

Permasalahan penggunaan bekatul sebagai bahan pangan adalah fungsionalitas dari senyawa bioaktif dari bekatul yang disebabkan oleh bentuknya yang terikat pada matriks senyawa lain, yaitu lignin (Zhang et al., 2010). Permasalahan lainnya terkait dengan palatabilitasnya yang kurang disukai. Salah satu metode yang dapat dilakukan untuk meningkatkan sifat fungsional senyawa fenolik dan $\gamma$ oryzanol sebagai antioksidan adalah dengan proses fermentasi. Rashid et al. (2015) menyatakan bahwa proses fermentasi dapat digunakan untuk melepaskan ikatan fitokimia sehingga dapat meningkatkan bentuk bebasnya dan bioavailabilitasnya. Ryan et al. (2011) melaporkan bahwa proses fermentasi juga dapat memperbaiki stabilitas, palatabilitas, dan nilai gizi bekatul. Fermentasi kapang dilaporkan dapat meningkatkan availabilitas senyawa bioaktif pada bekatul yang disebabkan oleh kemampuan kapang dalam mendegradasi matriks lignoselulosa dan polisakarida secara enzimatis (Schmidt dan Furlong, 2012). Total senyawa fenolik pada bekatul mengalami peningkatan $110 \%(2,4-5,1 \mathrm{mg} / \mathrm{g})$ setelah difermentasi dengan menggunakan kapang Rizhopus oryzae selama 120 jam (Schmidt et al., 2014;
Rashid et al (2015). Beberapa senyawa fenolik yang mengalami peningkatan setelah proses fermentasi yaitu asam ferulat $(14,7 \mathrm{mg} / \mathrm{g})$, galat $(2,6-154,5$ $\mathrm{mg} / \mathrm{g})$, klorogenat $(20,9-76,1 \mathrm{mg} / \mathrm{g})$, kafeat $(4,8-28,7$ $\mathrm{mg} / \mathrm{g})$, protokatekuat $(7,7-13,6 \mathrm{mg} / \mathrm{g})$, vanillin $(8,6$ $13,1 \mathrm{mg} / \mathrm{g}$ ) dan siringat $(2,1-12,7 \mathrm{mg} / \mathrm{g}$ ) (Schmidt et al., 2014). Aktivitas antioksidan juga mengalami peningkatan setelah fermentasi selama 120 jam (213$\left.250 \mathrm{mg} / \mathrm{g}_{\mathrm{DPPH}}\right)$. Pola serupa dijumpai pada penelitian Razak et al. (2015), yang memanfaatkan kultur tunggal dan kombinasi antara Rizhopus oligosporus dan Monascus purpureus. Komponen total senyawa fenolik memgalami peningkatan setelah fermentasi, yaitu dari $3,93 \mathrm{mg}$ EAG/g menjadi $7,54 \mathrm{mg} \mathrm{EAG/g}$ (dengan Rizhopus oligosporus), 7,69 mg EAG/g sampel (dengan Monascus purpureus) dan 8,13 mg EAG/g (dengan campuran Rizhopus oligosporus dan Monascus purpureus).

Senyawa $\gamma$-oryzanol adalah salah satu komponen paling penting pada bekatul. Antioksidan utama dalam bekatul beras adalah $\gamma$-oryzanol $(62,9 \%)$ dan asam fenolat (35,9\%) (Laokuldilok et al., 2011). Senyawa $\gamma$-oryzanol merupakan campuran ester asam ferulat dan alkohol triterpene. Komposisi $\gamma$-oryzanol dalam minyak bekatul sekitar 1-2\% yang berfungsi sebagai antioksidan alami. Senyawa $\gamma$-oryzanol mempunyai tiga komponen utama, yaitu cycloartenyl ferulat, 24-methylene cycloartenyl ferulat, dan campesteryl ferulate (Patel dan Naik, 2004). Kandungan $\gamma$-oryzanol pada bekatul beras hitam, beras merah dan beras putih berbeda-beda, yaitu 9,12; 8,58; dan $1,52 \mathrm{mg} / \mathrm{g}$ (Moongngarm et al., 2012; Jayadeep dan Malleshi, 2011). Rashid et al. (2015) melaporkan bahwa kandungan $\gamma$-oryzanol pada bekatul yang difermentasi dengan bakteri $P$. acidilactici mengalami peningkatan dari $954,47 \mu \mathrm{g} / \mathrm{mL}$ ekstrak menjadi $1148,38 \mu \mathrm{g} / \mathrm{mL}$ ekstrak.

Kandungan senyawa bioaktif bekatul dapat berbeda-beda yang dipengaruhi oleh varietas padi, sehingga bekatul dari sumber yang berbeda dapat memberikan efek aktivitas biologis yang berbeda (Sompong et al., 2011). Penelitian ini menggunakan tiga varietas padi yaitu inpari 24 , inpari 30 , dan koshihikari. Varietas Inpari merupakan padi yang banyak ditanam, karena tahan terhadap hama penyakit dan memiliki tekstur beras yang pulen yang disukai oleh masyarakat. Koshihikari merupakan jenis beras Jepang yang dapat ditanam di Indonesia dan sangat disukai oleh masyarakat. Penelitian ini bertujuan untuk mengevaluasi komposisi kimia $(\mathrm{pH}$, kadar air, abu, lemak, protein, dan karbohidrat), kandungan total senyawa fenolik, $\gamma$-oryzanol, dan aktivitas antioksidan dari bekatul padi Indica (beras putih varietas inpari 30 dan beras merah varietas inpari 24) dan Japonica (varietas koshihikari) yang difermentasi dengan menggunakan kapang Rizhopus oryzae. 


\section{BAHAN DAN METODE}

\section{Bahan}

Bahan utama yang digunakan dalam penelitian ini adalah bekatul jenis Indica dan Japonica dalam bentuk gabah kering giling. Padi jenis Indica yang digunakan adalah beras putih varietas inpari 30 dan beras merah varietas Inpari 24 yang diperoleh dari petani di Jasinga, Bogor, sedangkan padi jenis Japonica yang digunakan (Koshihikari) diperoleh dari Balai Besar Penelitian Padi, Sukamandi, Subang. Bahan lain yang digunakan yaitu inokulum berupa kapang Rizhopus oryzae (IPBCC 13.1138) yang diperoleh dari IPB Culture Collection, Institut Pertanian Bogor.

\section{Penyiapan bekatul}

Gabah kering giling dari masing-masing varietas dikupas kulitnya dengan mesin huller (Satake, Japan) untuk memperoleh beras pecah kulit. Selanjutnya, beras pecah kulit disosoh dengan rice mill (Satake, Japan) selama 2 menit. Proses sosoh ini menghasilkan beras sosoh dan campuran bekatul dan dedak. Campuran dedak dan bekatul ini kemudian dipisahkan dengan ayakan 20 mesh untuk mendapatkan bekatul. Bekatul yang diperoleh selanjutnya siap untuk difermentasi.

\section{Fermentasi bekatul (Schmidt et al., 2014; Razak et al., 2015)}

Substrat bekatul ditempatkan pada labu erlenmeyer $250 \mathrm{~mL}$, lalu ditambahkan air (perbandingan substrat dan air adalah 2:1) dan ditutup dengan kapas steril. Sampel selanjutnya disterilisari dengan autoklaf (ALP MC-40, Jerman), pada suhu $121^{\circ} \mathrm{C}$ selama 15 menit. Setelah didinginkan sampai suhu $30^{\circ} \mathrm{C}$, sampel diinokulasi dengan Rizhopus oryzae $\left(1,5 \times 10^{5} \mathrm{spora} / \mathrm{g}\right.$ bekatul). Sampel yang telah diinokulasi kemudian diinkubasi pada suhu $32^{\circ} \mathrm{C}$ selama $0,24,48,72,96$ dan 120 jam. Sampel yang telah difermentasi lalu dikering-kan dengan freeze dryer (Eyela, Model FDU-1100 DRC-1000 PFR-1000, Jepang), dan disimpan pada suhu $-18^{\circ} \mathrm{C}$ sampai waktu analisis. Sampel dianalisis aktivitas antioksidannya dan yang menunjukkan aktivitas antioksidan tertinggi dipilih untuk pengujian selanjutnya (analisis komposisi kimia, kadar total senyawa fenolik dan $\gamma$ oryzanol).

\section{Ekstraksi bekatul (Tuarita, 2017)}

Ekstraksi bekatul menggunakan pelarut metanol (Merck, AS) dengan perbandingan bekatul dan metanol sebesar 1:10 (\%b/v). Proses ekstraksi menggunakan metode maserasi selama 3 jam dengan menggunakan penangas air (WNB-7 Memmert, Jerman) pada suhu ruang $\left(30^{\circ} \mathrm{C}\right)$, dilanjutkan dengan sonikasi selama 10 menit. Filtrat dipisahkan dari residunya dengan cara disentrifugasi pada 3000 rpm selama 15 menit. Filtrat yang didapat disebut sebagai ekstrak bekatul yang digunakan dalam analisis.

\section{Analisis aktivitas antioksidan (Baba dan Malik, 2014)}

Aktivitas antioksidan pada ekstrak bekatul dianalisis dengan metode DPPH (2,2-diphenyl-1-picrylhydrazyl) radical scavenging. Sampel ekstrak bekatul $(200 \mu \mathrm{L})$ direaksikan dengan $3,8 \mathrm{~mL}$ larutan DPPH $(150 \mu \mathrm{M})$ (Merck, AS), kemudian diinkubasi selama 1 jam di ruangan gelap. Selanjutnya sampel diukur absorbansinya dengan UV-Vis spektrofotometer (UV-1800 Shimadzu, Jepang) pada panjang gelombang $517 \mathrm{~nm}$. Kontrol positif yang digunakan berupa Trolox (Sigma) dengan konsentrasi 100 hingga $400 \mathrm{mg} / \mathrm{g}$. Larutan blanko dibuat sesuai dengan tahap di atas namun dilakukan penggantian sampel dengan menggunakan metanol. Nilai absorbansi terkoreksi dihitung sebagai selisih dari absorbansi blanko dengan sampel. Aktivitas antioksidan dihitung dari perhitungan kurva kalibrasi larutan standar dan dinyatakan dalam \% scavenging.

\section{Analisis proksimat (AOAC, 2012)}

Sampel bekatul dianalisis komposisi kimianya (kadar air, abu, lemak, protein, dan karbohidrat). Kadar air diukur menggunakan metode gravimetrik, kadar abu dengan metode pengabuan kering, kadar lemak dengan metode soxhlet, kadar protein dengan metode kjeldahl, dan kadar karbohidrat dengan by difference.

\section{Analisis total senyawa fenolik (Baba dan Malik, 2014)}

Perhitungan komponen total senyawa fenolik dilakukan dengan reagen Folin-Ciocalteau. Sebanyak $200 \mu \mathrm{L}$ ekstrak bekatul $(1 \mathrm{mg} / \mathrm{mL})$ ditambahkan air demineralisasi sampai $3 \mathrm{~mL}$, lalu dicampur dengan $0,5 \mathrm{~mL}$ reagen Folin-Ciocalteu fenol (Merck, AS). Selanjutnya sampel ditambah $2 \mathrm{~mL}$ larutan natrium karbonat $(20 \% \mathrm{~b} / \mathrm{v})$ dan dikocok. Sampel diinkubasi pada suhu kamar selama 60 menit dengan kondisi gelap sebelum diukur nilai absorbansinya dengan UV-Vis spektrofotometer pada panjang gelombang $650 \mathrm{~nm}$. Total senyawa fenolik ditentukan dengan menggunakan larutan standar asam galat (Merck, AS). Kadar total senyawa fenolik dinyatakan dengan $\mathrm{mg}$ ekuivalen asam galat $(E A G) / g$.

\section{Analisis $\gamma$-oryzanol (Krishna et al., 2006)}

Ekstraksi $\gamma$-oryzanol dari bekatul dilakukan dengan metode maserasi menggunakan pelarut $n$-heksana. Sampel bekatul $(1 \mathrm{~g})$ ditambahkan larutan heksana (Merck, AS) $10 \mathrm{~mL}$ pada tabung sentrifus. Larutan divortex selama 2 menit, kemudian disentrifusi pada $3000 \mathrm{rpm}$ selama 20 menit. Sebanyak 1 $\mathrm{mL}$ supernatan diambil dan ditempatkan pada labu 
ukur $10 \mathrm{~mL}$, kemudian ditambah pelarut n-heksana. Sampel diukur dengan UV-Vis spektrofometer pada panjang gelombang pada $319 \mathrm{~nm}$. Senyawa $\gamma-$ oryzanol pada bekatul ditentukan dengan menggunakan larutan standar $\gamma$-oryzanol.

\section{Analisis data}

Percobaan menggunakan metode rancangan acak lengkap (RAL) satu faktor, yaitu jenis beras (Inpari 24, Inpari 30 dan Koshihikari). Percobaan dilakukan dengan dua kali ulangan. Bekatul dari masing-masing varietas yang tidak difermentasi dijadikan sebagai kontrol. Pengolahan data dilakukan dengan menggunakan perangkat lunak IBM SPSS 22.0. Data hasil analisis aktivitas antioksidan dan komposisi kimia diuji dengan analisis variansi (ANOVA) dan uji lanjut duncan multiple range test (DMRT) pada taraf signifikansi 5\%. Pada pengukuran total senyawa fenolik dan $\gamma$-oryzanol, data dianalisis dengan uji $\mathrm{T}$ pada taraf signifikansi $5 \%$. Uji Pearson dilakukan untuk menunjukkan ada tidaknya korelasi antar komponen yang dianalisis.

\section{HASIL DAN PEMBAHASAN}

\section{Aktivitas antioksidan}

Gambar 1 menunjukkan aktivitas antioksidan bekatul Inpari 24, Inpari 30 dan Koshihikari sebelum dan selama proses fermentasi oleh Rizhopus oryzae. Bekatul non-fermentasi dari ketiga jenis beras menunjukkan aktivitas oksidan, yaitu 75,07\% (untuk Inpari 24), 73,92\% (untuk Inpari 30) dan 75,20\% (untuk Koshihikari). Secara umum, bekatul yang difermentasi memiliki aktivitas antioksidan yang lebih tinggi dibandingkan bekatul non-fermentasi, yang dipengaruhi oleh lamanya waktu fermentasi. Ketiga jenis bekatul yang difermentasi selama 24-120 jam menunjukkan, aktivitas antioksidan lebih tinggi $(P<$ $0,05)$ dibandingkan bekatul non-fermentasi, yaitu pada rentang $75,34 \%$ hingga $78,92 \%$. Aktivitas antioksidan meningkat 5,0\% dibandingkan bekatul nonfermentasi hingga waktu fermentasi selama 72 jam, namun cenderung menurun bila waktu fermentasi diperpanjang hingga 120 jam. Penurunan aktivitas antioksidan disebabkan oleh kompetisi kapang dalam memperoleh nutrisi dan substrat yang menyebabkan penurunan produksi enzim pemecah lignin oleh kapang. Perubahan yang terjadi selama fermentasi dipengaruhi oleh jenis substrat, kapang yang digunakan, dan kondisi fermentasi (Schmidt dan Furlong, 2012). Hal yang sama dilaporkan oleh Razak et al. (2015) yaitu aktivitas antioksidan meningkat 3,0\% setelah proses fermentasi selama 12 hari. Komponen asam fenolat seperti asam galat, protokatekuat, dan kafeat juga menunjukkan peningkatan tertinggi.
Peningkatan aktivitas antioksidan pada sampel bekatul fermentasi diduga sebagai konsekuensi meningkatnya komponen fenolik bebas seperti asam ferulat, asam galat (Schmidt et al., 2014), antosianin dan oryzanol (Jun et al., 2015). Peningkatan asam fenolat pada bekatul fermentasi disebabkan oleh pemecahan selulosa dan hemiselulosa dengan lignin (komponen struktural dinding sel) (Schmidt dan Furlong, 2012). Kapang menghasilkan enzim pemecah lignin dan memiliki kemampuan sistem oksidatif ligniolitik yang mendegradasi cincin fenil sehingga meningkatkan komponen fenol bebas (Martins et al., 2011). Menurut Razak et al. (2015), komponen fenolik seperti asam ferulat (komponen fenolik utama pada bekatul) dapat bertindak sebagai radical scavengers terhadap DPPH dan NO (nitrogen oksida).

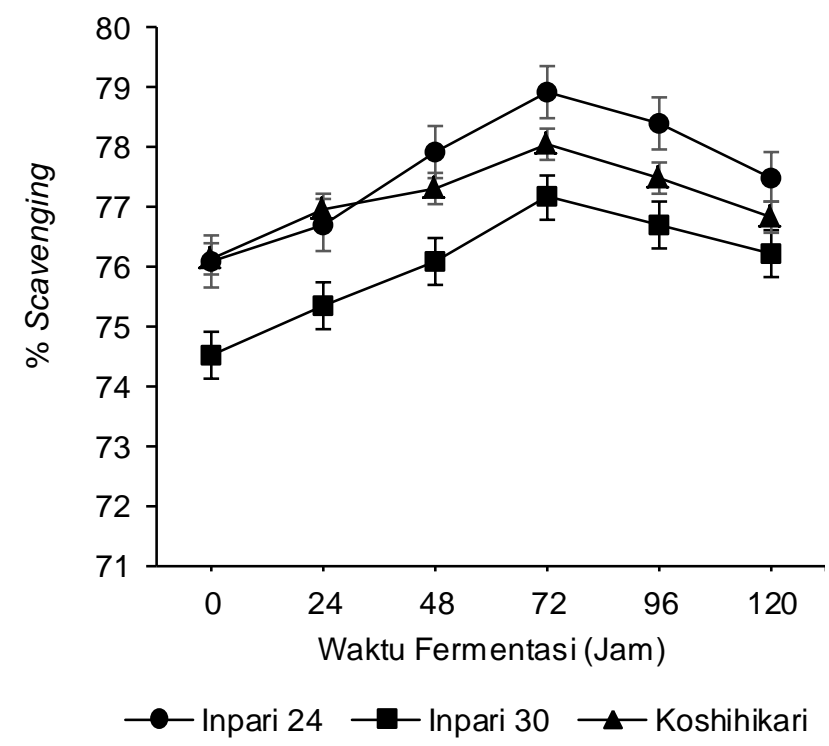

Gambar 1. Perubahan aktivitas antioksidan bekatul yang difermentasi dengan Rizhopus oryzae

Gambar 1 menunjukkan bahwa varietas Inpari 24 memiliki aktivitas antioksidan yang lebih tinggi dibanding Inpari 30 dan Koshihikari. Hal ini karena bekatul beras merah mempunyai kadar total senyawa fenolik dan $\gamma$-oryzanol lebih tinggi dibandingkan bekatul lainnya. Senyawa fenolik dan $\gamma$-oryzanol terbukti mampu mencegah oksidasi dan radikal bebas. Inpari 24 merupakan jenis beras merah yang diketahui memiliki pigmen antosianin yang berfungsi sebagai antioksidan. Muntana dan Prasong (2010) menyatakan bahwa perbedaan profil dan kadar pigmen antosianin dipengaruhi oleh warna bekatul beras. Sebagian besar asam fenolik (83-97\%) yang terdapat pada beras berpigmen berada dalam bentuk terikat dengan komponen lain. Asam fenolik yang banyak terdapat pada beras merah adalah asam ferulat dan asam protokatekat, yaitu berkisar 2,9-3,9 $\mathrm{mg} / 100 \mathrm{~g}$ (Sompong et al., 2011). Moko et al. (2014) 
melaporkan bahwa bekatul beras putih (varietas Superwin dan Cigeulis) mengandung komponen fenolik, flavonoid, alkaloid, triterpenoid, steroid, dan tanin serta antosianin yang lebih rendah disbandingkan beras merah. Bekatul beras merah memiliki komponen fenolik lebih tinggi $(4,3 \mathrm{mg} / \mathrm{g})$ disbandingkan bekatul beras putih $(1,96 \mathrm{mg} / \mathrm{g}$ ) (Moongngarm et al., 2012).

Berdasarkan hasil pengujian aktivitas antioksidan sebagaimana diuraikan di atas, maka sampel bekatul yang difermentasi selama 72 jam memiliki aktivitas antioksidan yang tertinggi dibandingkan waktu fermentasi lainnya. Waktu fermentasi tersebut kemudian dipilih untuk analisis lebih lanjut (komposisi kimia, kadar total senyawa fenolik dan kadar $\gamma$ oryzanol).

\section{Komposisi kimia}

Bekatul non-fermentasi dari tiga varietas memiliki komposisi kimia yang berbeda (Tabel 1). Hal ini sejalan dengan yang dilaporkan oleh Hartati et al. (2015) yang menunjukkan komposisi kimia yang berbeda dari bekatul varietas padi IR-64, Sintanur, Rajalele, dan Menthik wangi. Komposisi kimia bekatul yang beragam dipengaruhi oleh varietas, proses penggilingan, lingkungan tempat padi tumbuh, dan derajat penggilingan gabah.

Tabel 1 menyajikan komposisi kimia dari tiga sampel bekatul sebelum dan setelah fermentasi selama 72 jam. Secara umum, proses fermentasi mengubah komposisi kimia secara nyata $(P<0,05)$. Kadar air, kadar abu dan kadar protein dari ketiga bekatul yang difermentasi selama 72 jam meningkat, sedangkan kadar lemak dan karbohidrat menurun. Peningkatan kadar air disebabkan oleh aktivitas metabolisme kapang yang menghasilkan air sebagai hasil sampingnya. Penurunan kadar lemak disebabkan oleh aktivitas kapang dalam menggunakan lemak sebagai sumber energi untuk sintesis miselium. Perubahan komposisi kimia ini sejalan dengan yang dilaporkan oleh Oliveira et al. (2010), yang menunjukkan terjadinya peningkatan kadar air, kadar abu, serat, dan asam fitat, namun terjadi penurunan pada kadar lemak dan gula reduksi pada bekatul yang difermentasi dengan menggunakan Rizhopus oryzae selama 120 jam. Perubahan komposisi kimia yang terjadi pada bekatul fermentasi diduga disebabkan oleh penambahan massa yang berasal dari kapang yang digunakan pada saat proses fermentasi.

Proses fermentasi dapat mengubah komposisi kimia yang disebabkan oleh produksi enzim ekstraselular oleh mikroorganisme untuk mendapatkan nutrisi dan hasil samping dari metabolit lainnya. Metabolisme ini dapat memperkaya nutrisi pada substrat, tergantung pada komponen yang terdapat pada agen fermentasi atau ketersediaan nutrisi pada substrat tersebut (Oliveira et al., 2010).

\section{Kadar total senyawa fenolik}

Gambar 2 menunjukkan hasil analisis kandungan total senyawa fenolik pada bekatul non-fermentasi dan yang difermentasi selama 72 jam. Bekatul sebelum difermentasi mengandung kadar total senyawa fenolik sebesar 3,29 mg EAG/g (Inpari 24), 3,13 mg EAG/g (Inpari 30) dan 3,12 mg EAG/g (Koshihikari). Arab et al. (2011) juga melaporkan kadar total senyawa fenolik yang berbeda dari bekatul varietas padi Fajr dan Tarem masing-masing sebesar 0,331 $\mathrm{mg}$ EAG/g dan 0,201 mg EAG/g.

Berdasarkan Gambar 2, maka bekatul Inpari 24 menunjukkan kadar total senyawa fenolik yang lebih tinggi dibandingkan Inpari 30 dan Koshihikari. Seperti dijelaskan di atas, Inpari 24 merupakan varietas padi merah yang memiliki pigmen warna dan menunjukkan akivitas antioksidan yang tertinggi. Analisis korelasi Pearson menunjukkan bahwa total senyawa fenolik memiliki korelasi positif $(0,96)$ yang sangat nyata $(P<0,01)$ dengan nilai aktivitas antioksidan. Hal ini sejalan dengan Rashid et al. (2015), bahwa aktivitas antioksidan pada bekatul non-fermentasi dan bekatul fermentasi memiliki korelasi yang tinggi dengan kontribusi seluruh komponen bioaktif di dalamnya dan tidak spesifik pada komponen-komponen fenoliknya saja.

Tabel 1. Karakteristik bekatul non-fermentasi dan bekatul yang difermentasi dengan Rizhopus oryzae selama 72 jam

\begin{tabular}{|c|c|c|c|c|c|c|}
\hline \multirow[b]{2}{*}{ Karakteristik } & \multicolumn{2}{|c|}{ Inpari 24} & \multicolumn{2}{|c|}{ Inpari 30} & \multicolumn{2}{|c|}{ Koshihikari } \\
\hline & $\begin{array}{c}\text { Non- } \\
\text { Fermentasi }\end{array}$ & Fermentasi & $\begin{array}{c}\text { Non- } \\
\text { Fermentasi }\end{array}$ & Fermentasi & $\begin{array}{c}\text { Non- } \\
\text { Fermentasi }\end{array}$ & Fermentasi \\
\hline Kadar air (\% bb) & $2,09 \pm 0,35^{c}$ & $4,77 \pm 0,76^{\text {ab }}$ & $4,84 \pm 0,59^{a b}$ & $4,95 \pm 0,22^{a b}$ & $3,69 \pm 0,32^{b}$ & $5,73 \pm 0,63^{a}$ \\
\hline Kadar abu (\% bk) & $7,66 \pm 0,06^{c}$ & $10,21 \pm 0,00^{b}$ & $9,61 \pm 0,93^{b}$ & $12,73 \pm 0,03^{a}$ & $9,04 \pm 0,06^{b}$ & $12,54 \pm 0,63^{a}$ \\
\hline Lemak (\% bk) & $14,52 \pm 0,27^{b}$ & $13,38 \pm 3.84^{b}$ & $16,29 \pm 0,35^{b}$ & $12,90 \pm 0,25^{b}$ & $22,26 \pm 0,10^{a}$ & $21,03 \pm 1,98^{a}$ \\
\hline Protein(\% bk) & $14,77 \pm 0,90^{c}$ & $18,53 \pm 1,55^{\mathrm{abc}}$ & $14,30 \pm 1,55^{\mathrm{c}}$ & $20,66 \pm 0,81^{a b}$ & $17,10 \pm 0,44^{\mathrm{bc}}$ & $22,37 \pm 3,14^{a}$ \\
\hline Karbohidrat (\% bk) & $63,06 \pm 0,57^{a}$ & $57,88 \pm 2,29^{\mathrm{bc}}$ & $59,80 \pm 0,27^{b}$ & $53,78 \pm 1,03^{c}$ & $51,60 \pm 0,48^{c}$ & $44,07 \pm 5,75^{d}$ \\
\hline Aktivitas antioksidan (\%) & $75,07^{d}$ & $78,92^{\mathrm{e}}$ & $73,92^{d}$ & $77,16^{a}$ & $75,20^{c}$ & $78,04^{b}$ \\
\hline
\end{tabular}




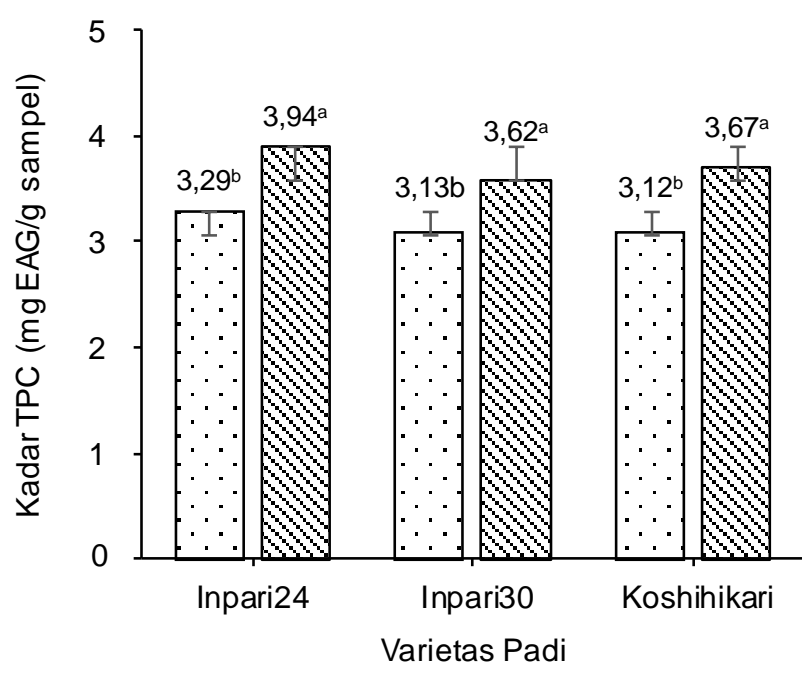

№n-fermentasi $\quad$ Fermentasi

Gambar 2. Kadar total senyawa fenolik bekatul non-fermentasi dan yang difermentasi dengan Rizhopus oryzae selama 72 jam

Muntana dan Prasong (2010) menjelaskan bahwa perbedaan kadar pigmen antosianin dipengaruhi oleh perbedaan warna pada bekatul beras. Sebagian besar asam fenolik (83-97\%) yang terdapat pada beras berpigmen berada dalam bentuk terikat dengan komponen lain. Asam fenolik yang banyak terdapat pada beras merah adalah asam ferulat dan asam protokatekat berkisar 2,9-3,9 mg/100 g (Sompong et al., 2011). Moko et al. (2014) melaporkan bahwa bekatul beras putih (varietas Superwin dan Cigeulis) mengandung komponen fenolik, flavonoid, alkaloid, triterpenoid, steroid, dan tanin serta antosianin yang lebih rendah bila dibandingkan beras merah. Bekatul beras merah memiliki komponen fenolik lebih tinggi yaitu $4,3 \mathrm{mg} / \mathrm{g}$ dibandingkan bekatul beras putih yaitu $1,96 \mathrm{mg} / \mathrm{g}$ (Moongngarm et al., 2012).

Hasil analisis ragam menunjukkan terdapat perbedaan yang nyata $(P<0,05)$ antara kadar total senyawa fenolik dari bekatul non-fermentasi dengan bekatul yang difermentasi selama 72 jam. Bekatul yang difermentasi selama 72 jam meningkat kadar total senyawa fenoliknya dibandingkan bekatul nonfermentasi, yaitu sebesar 18\% (Inpari 24), 16\% (Inpari 30) dan 19\% (Koshihikari). Kandungan total senyawa fenolik tertinggi ditunjukkan oleh bekatul Inpari 24 terfermentasi, yaitu 3,94 mg EAG/g. Hasil penelitian ini lebih rendah dibandingkan dengan yang dilaporkan oleh Schmidt et al. (2014), yaitu meningkat sebesar $110 \%$. Perbedaan ini disebabkan waktu fermentasi yang digunakan (120 jam), di samping juga perbedaan varietas padi yang digunakan. Namun, dari hasil penelitian dapat dilihat bahwa proses fermentasi dapat meningkatkan komponen total senyawa fenolik.
Proses fermentasi diduga meningkatkan ketersediaan asam-asam fenolik bebas, sehingga bekatul fermentasi memiliki total senyawa fenolik lebih tinggi. Peningkatan fenolik bebas diakibatkan aktivitas hidrolitik enzimatis ekstraseluler mikroba selama fermentasi. Selain itu, kapang juga dapat memproduksi senyawa fenolik. Razak et al. (2015) melaporkan bahwa kapang dapat memproduksi enzim yang berperan dalam proses hidrolitik enzimatis, yaitu $\beta$ glukosidase. Enzim $\beta$-glukosidase berperan sebagai katalis dalam proses hidrolisis ikatan glikosida pada gugus alkil dan aril $\beta$-D-glukosida. Enzim tersebut menghidrolisis glikosida fenolik sehingga melepaskannya menjadi asam fenolik bebas. Sebagaimana dijelaskan di atas, Rizhopus oryzae menghasilkan enzim pemecah karbohidrat dan memiliki kemampuan sistem oksidatif lignolitik yang mendegradasi cincin fenil yang dapat meningkatkan komponen fenol bebas (Martin et al., 2011). Lakase merupakan salah satu enzim lignolitik yang banyak mengandung tembaga oksidase dan mempunyai kemampuan untuk mengoksidasi senyawa fenol. Reaksi enzimatik pada enzim lakase merupakan reaksi oksidasi yang menghasilkan satu elektron hasil oksidasi senyawa fenol dan mereduksi oksigen menjadi air (Sigit, 2008). Kapang jenis Rhizopus sp memliki kemampuan untuk memproduksi enzim lakase. Reksohadiwinoto et al. (2017) melaporkan bahwa aktivitas enzim lakase pada fermentasi dengan menggunakan Rhizopus oligosporus meningkat selama fermentasi. Pada hari ke-0 fermentasi, lakase tidak memiliki aktivitas, namun aktivitas meningkat menjadi $0,297 \mathrm{U} / \mathrm{mL}$ (hari ke-3) dan $3,55 \mathrm{U} / \mathrm{mL}$ (hari ke$6)$.

\section{Kadar $\gamma$-oryzanol}

Hasil pengukuran terhadap kadar $\gamma$-oryzanol pada hasil ekstraksi bekatul sebelum dan setelah fermentasi disajikan pada Gambar 3. Bekatul nonfermentasi dari Inpari 24 memiliki kadar $\gamma$-oryzanol tertinggi $(11,21 \mathrm{mg} / \mathrm{g})$ dibandingkan Inpari $30(9,01$ $\mathrm{mg} / \mathrm{g}$ ) dan Koshihikari $(10,13 \mathrm{mg} / \mathrm{g})$. Mumpuni dan Ayustaningwarno (2013) juga menunjukkan perbedaan kadar $\gamma$-oryzanol dari bekatul varietas yang berbeda, yaitu varietas Mansur $(13,34 \mathrm{mg} / \mathrm{g})$, beras Taun merah $(24,20 \mathrm{mg} / \mathrm{g})$, dan beras taun hitam $(15,01 \mathrm{mg} / \mathrm{g})$. Moongngarm et al. (2012) juga melaporkan bahwa kandungan $\gamma$-oryzanol pada beras hitam, beras merah dan beras putih berturut-turut sebesar 9,12; 8,58; dan 1,52 mg/g.

Perlakuan fermentasi selama 72 jam pada bekatul menghasilkan komponen $\gamma$-oryzanol yang meningkat sebesar 13-19\%. Hasil penelitian ini lebih rendah dibandingkan dengan yang dilaporkan oleh Rashid et al. (2015), yaitu kandungan $\gamma$-oryzanol pada bekatul yang difermentasi dengan menggunakan bakteri $P$. acidilactici meningkat sebesar $20 \%$. 
Perbedaan hasil ini disebabkan oleh penggunaan mikroba dan metode fermentasi yang berbeda.

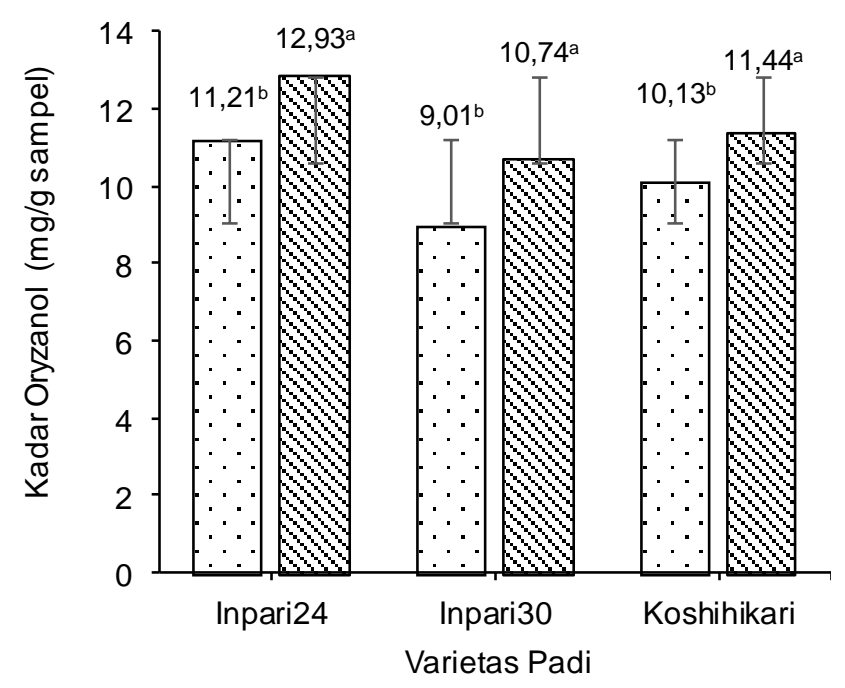

$\square$ Non-fermentasi $\mathbf{Q}$ Fermentasi

Gambar 3. Kadar $\gamma$-oryzanol bekatul non-fermentasi dan yang difermentasi dengan Rizhopus oryzae selama 72 jam

Schmidt et al. (2014) melaporkan bahwa proses fermentasi bekatul menggunakan Rizhopus oryzae meningkatkan senyawa fenolik (asam ferulat, galat, klorogenat, kafeat, $p$-kumarat, protokatekuat, vanilin dan siringat). Peningkatan asam fenolat pada bekatul fermentasi disebabkan pemecahan komponen kompleks dengan lignin oleh enzim metabolit dari Rizhopus oryzae (Schmidt dan Furlong, 2012). Alasan yang sama yang dapat menjelaskan hasil di atas, yaitu oleh kemampuan Rizhopus oryzae dalam memproduksi enzim pemecah ikatan kompleks dengan lignin yang dapat meningkatkan kandungan $\gamma$ oryzanol dalam bekatul terfermentasi.

Uji korelasi Pearson menunjukkan bahwa kadar $\gamma$-oryzanol berkorelasi positif $(0,87)$ sangat nyata $(P<0,01)$ dengan aktivitas antioksidan. Hal ini sejalan dengan Jun et al. (2015) yang menyatakan, bahwa aktivitas antioksidan bekatul sangat dipengaruhi keberadaan asam-asam fenolik (asam ferulat, asam galat, kafeat, $p$-kumarat, protokatekuat, vanilat dan siringat) dan beberapa komponen bioaktif lainnya seperti antosianin, $\gamma$-oryzanol, tokotrienol, dan tokoferol. Semakin tinggi konsentrasi komponen bioaktif dengan sifat fungsional antioksidan tersebut, maka semakin tinggi pula aktivitas sifat fungsionalnya sebagai antioksidan.

\section{KESIMPULAN}

Bekatul dari padi varietas Inpari 24, Inpari 30 dan Koshihikari yang difermentasi dengan Rizhopus oryzae mengalami peningkatan aktivitas antioksidan, perubahan komposisi kimia, dan peningkatan kadar total senyawa fenolik dan kadar $\gamma$-oryzanol dibandingkan bekatul non-fermentasi. Ketiga bekatul yang difermentasi selama 72 jam menunjukkan peningkatan aktivitas antioksidan tertinggi, dengan kadar total senyawa fenolik dan kadar $\gamma$-oryzanol yang meningkat secara berturut-turut menjadi $3,6-3,9 \mathrm{mg}$ EAG/g dan 10,74-12,93 mg/g. Bekatul dari Inpari 24 menunjukkan aktivitas antioksidan, kadar total senyawa fenolik, dan kadar $\gamma$-oryzanol tertinggi, baik sebelum maupun setelah fermentasi 72 jam. Aktivitas antioksidan, total senyawa fenolik dan $\gamma$-oryzanol dari bekatul yang difermentasi pada kondisi tersebut secara berturut-turut mengalami peningkatan sebesar 3,73; 19,76; dan 15,34\% dibandingkan bekatul tanpa fermentasi.

\section{DAFTAR PUSTAKA}

[AOAC] Association of Official Analytical Chemistry. 2012. Official Method of Analysis. Association of Official Analytical Chemistry 19th Edition. AOAC Inc, Gaithersburg (US).

Arab F, Alemzadeh I, Maghsoudi V. 2011. Determination of antioxidant component and activity of rice bran extract. Sci Iran Transactions C: Chem Chem Eng 18: 1402-1406. DOI: 10.1016/ j.scient.2011.09.014.

Baba SA, Malik SA. 2015. Determination of total phenolic and flavonoid content, antimicrobial and antioxidant activity of a root extract of Arisaema jacquemontii. J Taibah University Sci 9: 449-454 DOI: 10.1016/j.jtusci.2014.11.001.

[BPS] Badan Pusat Statistik. 2018. Luas panen dan produksi padi di Indonesia. http://www.bps.go. id. [02 Januari 2019].

Esa NM, Ling TB, Peng LS. 2013. By-product of rice processing: An overview of health benefits and application. J Rice Res 1: 107-117. DOI: 10.417 2/jrr.1000107.

Forster GM, Raina K, Kumar A, Kumar S, Agarwal $\mathrm{R}$, Chen MH, Bauer JE, McClung AM, Ryan EP. 2013. Rice varietal differences in bioactive bran components for inhibition of colorectal cancer cell growth. Food Chem 141: 1545-1552. DOI: 10.1016/j.foodchem.2013.04.020. 
Gul K, Yousuf B, Singh AK, Singh P, Wani AA. 2015. Rice bran: Nutritional values and its emerging potential for development of functional food - a review. Bioactive Carbohyd Dietary Fibre 6: 24-30. DOI: 10.1016/j.bcdf.2015.06. 002.

Hartati S, Marsono Y, Suparmo, Santoso U. 2015. Komposisi kimia serta aktivitas antioksidan eks trak hidrofilik bekatul beberapa varietas padi. J Agritech 35: 35-42. DOI: 10.22146/agritech. 9417.

Henderson AJ, Ollila CA, Kumar A, Borresen EC, Raina K, Agarwal R, Ryan EP. 2012. Chemopreventive properties of dietary rice bran: current status and future prospects. Adv Nutr 3: 643-653. DOI: 10.3945/an.112.002303.

Islam MS, Nagasaka R, Ohara K, Hosoya T, Ozaki $H$, Ushio $H$, Hori M. 2011. Biological abilities of rice bran derived antioxidant phytochemicals for medical therapy - a review. Curr Top Med Chem 11: 1847-1853. DOI: 10.2174/15680261 1796235099

Jayadeep A, Malleshi NG. 2011. Nutrients, composition of tocotrienols, tocopherols, and $\mathrm{Y}$-oryzanol, and antioxidant activity in brown rice before and after biotransformation. CyTA-J Food 9: 8287. DOI: $10.1080 / 19476331003686866$.

Jun HI, Shin JW, Yang GS, Kim YS. 2015. Isolation and identification of phenolic antioxidants in black rice bran. J Food Sci 80: 262-268. DOI: 10.1111/1750-3841.12754.

Krishna AGG, Hemakumar KH, Khaton S. 2006. Study on the composition of rice bran oil and its higher free fatty acids value. J Am Oil Chem Soc 83: 117-120. DOI: 10.1007/s11746-0061183-1.

Laokuldilok T, Shoemaker CF, Jongkaewwattana S. 2011. Antioxidants and antioxidant activity of several pigmented rice brans. J Agric Food Chem 59: 193-199. DOI: 10.1021/jf103649q.

Martins S, Mussatto SI, Martinez AG, Montanez SJ, Aguilar CN, Teixeira JA. 2011. Bioactive phenolic compounds: Production and extraction by solid-state fermentation - a review. Biotech Adv 29: 365-373. DOI: 10.1016/j.biotechadv.2011. 01.008.

Moko EM, Purnomo H, Kusnadi J, ljong FG. 2014. Phytochemical content and antioxidant properties of colored and non-colored varieties of rice bran from Minahasa, North Sulawesi, Indonesia. Int Food Res J 21: 1053-1059.
Moongngarm A, Daomukda N, Khumpika S. 2012. Chemical compositions, phytochemicals, and antioxidant capacity of rice bran, rice bran layer, and rice germ. Asia-Pac Chem, Biol Environ Eng (APCBEE) Proc 2: 73-79. DOI: 10.1016/j. apcbee.2012.06.014.

Mumpuni PD, Ayustaningwarno F. 2013. Analisis kadar tokoferol, $\gamma$-oryzanol dan $\beta$-karoten serta aktivitas antioksidan minyak bekatul kasar. J Nutr College 2: 350-357. DOI: 10.14710/jnc. v2i3.3436.

Muntana N, Prasong S. 2010. Study on total phenolic contents and their antioxidant activities of Thai white, red, and black rice bran extracts. Pakistan J Biol Sci 13: 170-174. DOI: 10.3923/ pjbs.2010.170.174.

Oliveira MS, Fedden V, Kupski L, Cipolatti EP, Furlong EB, Soares LS. 2010. Physico-chemical characterization of fermented rice bran biomass. CyTA-J Food 8: 229-236. DOI: 10.1080/ 19476330903450274.

Patel M, Naik SN. 2004. Gamma-oryzanol from rice bran oil - a review. J Sci Ind Res 63: 569-578.

Rashid NYA, Razak DLA, Jamaluddin A, Sharifuddin SA, Long K. 2015. Bioactive compounds and antioxidant activity of rice bran fermented with lactic acid bacteria. Malaysian J Microbiol 11: 156-162. DOI: 10.21161/mjm.12714.

Razak DLA, Rashid NYAR, Jamaluddin A, Sharifudin SA, Long K. 2015. Enhancement of phenolic acid content and antioxidant activity of rice bran fermented with Rhizopus oligosporus and Monascus purpureus. Biocatal Agric Biotechnol 4: 33-38. DOI 10.1016/j.bcab.2014.11.003.

Reksohadiwinoto BS, Rosmalawati S, Cahyana PT, dan Hariyanto B. 2017. Enzim laccase dari edible mushroom untuk pemutihan pati sagu ramah lingkungan. J Teknol Lingkungan 18: 224-332. DOI: 10.29122/jtl.v18i2.1790.

Ryan EP, Heuberger AL, Weir TL, Barnett B, Broeckling CD, Prenni JE. 2011. Rice bran fermented with Saccharomyces boulardii generates novel metabolite profile with bioactivity. J Agric Food Chem 59: 1862-1870. DOI: 10.1021/jf1038103.

Schmidt CG, Furlong EB. 2012. Effect of particle size and ammonium sulfate concentration on rice bran fermentation with the fungus Rhizopus oryzae. Bioresource Technology 123: 36-41. DOI: 10.1016/j.biortech.2012.07.081.

Schmidt CG, Goncalves LM, Prietto L, Hackbart HS, Furlong EB. 2014. Antioxidant activity and enzyme inhibition of phenolic acids from fermented rice bran with fungus Rizhopus oryzae. Food Chem 124: 132-140. DOI: 10.1016/j.food chem.2013.09.101. 
Sigit AM. 2008. Pola aktivitas enzim lignolitik jamur tiram (Pleurotus ostreatus) [Skripsi]. Bogor: Fakultas Matematika dan Pengetahuan Alam, Institut Pertanian Bogor.

Sompong $R$, Siebenhandl ES, Linsberger MG, Berghofer E. 2011. Physicochemical and antioxidative properties of red and black rice varieties from Thailand, China and Sri Lanka. Food Chem 124: 132-140. DOI: 10.1016/j.food chem.2010.05.115.

Sukma LN, Zackiyah, Gumilar GG. 2010. Pengkayaan asam lemak tak jenuh pada bekatul dengan cara fermentasi padat menggunakan Aspergillus terreus. J Sains Teknol Kimia 1: 66-72.

Tuarita MZ. 2017. Identifikasi Senyawa Sitotoksik dan Antioksidan dari Berbagai Jenis Bekatul dengan Pendekatan Metabolomik [Tesis]. Bogor: Fakultas Teknologi Pertanian, Institut Pertanian Bogor.

Zhang MW, Zhang RF, Zhang FX, Liu RH. 2010. Phenolic profiles and antioxidant activity of black rice bran of different commercially available varieties. J Agric Food Chem 58: 75807587. DOI: $10.1021 /$ jf1007665. 